\title{
2 \\ Chinese power and the idea of a responsible state
}

\section{Rosemary Foot}

The interrelated themes of 'power and responsibility' are useful tools for understanding Chinese foreign policy during a troubled yet remarkable span of half a century of Communist Party rule. Evaluations of the behaviour of the People's Republic of China (PRC) over these five decades have often related directly to concerns about the use the PRC has made of its material and ideological resources. Has Beijing worked to support the dominant norms of the international order, or has it striven to overturn them? Has it ever deserved to be termed a 'responsible power', as the dominant states in the system have sought to define that term, or has it acted irresponsibly? To place this more explicitly within an international relations framework, has China shown itself since 1949, and more especially during the period of reform and opening since 1979, as capable of being socialised into supporting global norms, or have there been signs that its rising power over the past two decades-as realists would predict-has generated new tensions in the international system? Looking more to the future, what kind of challenge does its enhanced capabilities pose to the status quo?'

This chapter links the concept of power to the idea of a responsible state, or more exactly and in reference to an important body of writing in international relations, it links power and 
responsibility with those states that are judged to belong to international society. It tries to respond, therefore, to the question of whether China has had a responsible government over the past 50 years by connecting this assessment of its behaviour with the concept of international society. Writing in 1977, and building on the earlier work of Martin Wight and others, Hedley Bull argued that international society exists when a group of powerful states recognise that they share certain common interests from which limited rules of coexistence can be derived, and exhibit a willingness to share in the working of institutions that maintain those arrangements. Importantly, international society in this formulation acknowledges diversity in values but also a set of reciprocal interests. $^{2}$

When the People's Republic of China was established in 1949, it undoubtedly posed a major challenge to those common interests and the rules that had been developed to underpin them, a challenge that lessened over time as China experimented with new forms of participation in the global system in the wake of its decision in the early 1970s to emerge from isolation and its later decision to embark on far-reaching reforms. At the time that China was beginning to move in this direction, however, those membership criteria were themselves undergoing change, embracing requirements beyond those that Bull had regarded as essential to include solidarist rather than pluralist conceptions of international society. Under these solidarist conceptions, common values and some notion of the common good, rather than the independent if common interests of sovereign and diverse states, were given priority. ${ }^{3}$ Thus, Beijing found that it was lagging behind the dominant definitions of the responsible state soon after it had decided to become more fully integrated into international society. Moreover, the changes in definition posed particular dilemmas for a government keen to be recognised as a Great Power, yet vulnerable to certain of the criteria that more recently had become associated with the modern state in international society, especially those that shone the spotlight more directly on the domestic organisation of states. ${ }^{4}$ 


\section{The responsible state and international society}

Great Powers in Hedley Bull's estimation derived that identity from characteristics that included but went beyond capacity, particularly military capacity. Such states also had to involve themselves in the provision of international order; indeed, they had special rights and duties when it came to maintaining order. This custodial role required agreement on a set of core and reciprocal interests, and then on the sets of institutions-such as war, diplomacy, international law, and the balance of power-that needed to be utilised in order to fulfil these requirements. Great Powers formed the core of international society not only because they shared an important set of interests and could generate a set of rules, but because they were capable of passing these rules on to others within the system. As Chinese leaders of the late nineteenth and early twentieth century discovered, the standard for their country to satisfy at a minimum involved the protection of the lives and property of foreign nationals, the conduct of diplomatic relations through the institutions of ambassadors and a foreign ministry, and an embrace of international law. In this particular understanding of international society, sovereign statusthat is, internal supremacy and external independence from outside interference- was seen as an essential starting point.

In more recent times, the UN Charter and the institution of the Security Council has been taken to reflect at least one important element of this Great Power management role. Article 2 of the Charter acknowledges the sovereign equality of states, and the norm of non-interference in domestic affairs. In addition, it emphasises the need for the pacific settlement of disputes and the non-use of force except for purposes of self-defence. In the first three post-war decades, states that generally supported these rules and that recognised the benefits that these norms of behaviour bestowed were designated responsible and capable of being embraced within the society of states. Those that rejected them were shunned, deemed irresponsible, and perceived as subversive 
of international order. Although other articles in the Charter limited the absolute rights of sovereignty and made reference to the need to promote human rights and fundamental freedoms for all, for most of the Cold War period, the Charter was interpreted in such a way as to keep the main focus on inter-state relations and to underpin the norm of non-intervention.

\section{Revolutionary China in the 1950 s and 1960 s}

One such state that appeared to have rejected this status quo definition of international society was the People's Republic of China, established in October 1949. Its discourse, and much of its behaviour, suggested that it was not prepared to play entirely by the rules. The vigour with which it launched its challenge and its decision to make common cause with the Soviet Union gave meaning to the belief that not only had two power blocs come into being, but so had two ideological systems. In the early years of the PRC's existence, the new revolutionary state refused to take on automatically the diplomatic obligations that it had inherited from the Nationalist government, preferring as Mao described it, to 'open a new stove' and to 'sweep the house clean before entertaining new guests'. The arrest in Shenyang of the US ConsulGeneral, Angus Ward, on 24 October 1949, on the spurious charge that Ward had 'seriously injured' a Chinese messenger at the Consulate, raised fears in the United States that diplomatic immunity would not be respected by the new Chinese government. China's primary goal in 1949, as the Foreign Minister Zhou Enlai put it, was to obtain swift recognition and establish 'brotherly friendship' with the Soviet Union and its socialist allies, while at the same time being 'hostile to the imperialists and to oppose them'. Moreover, the Chinese leadership took more seriously than we once believed Stalin's invitation to Beijing to take responsibility for supporting revolutions in Asia, as its aid to Kim II Sung's and Ho Chi Minh's plans for reunification and independent statehood demonstrated.' Beijing's decisions to assist with these struggles in Korea and Vietnam, assistance which has been described as crucial to the defeat of the French in Vietnam in 1954 and to 
North Vietnam's ability to resist American might in the period 1965-68, stemmed in some considerable part from its ideas of socialist solidarity and commitment to world revolution. Its later material and verbal support for armed struggles in the ThirdWorld, together with its-albeit selective- support for Communist Parties in states ruled by the bourgeoisie also contributed to an image of a Chinese world order that saw virtue in contention and upheaval, not in order and stability. ${ }^{8}$ Unsettled border claims and the continuation of the civil war struggle with the Nationalists on Taiwan regularly resulted in violence, representing-alongside its activities in support of the revolutionary struggles in Southeast Asia-direct challenges to the norms of non-interference and nonuse of force.

What made these challenges particularly potent in the 1950 s were that this apparent rejection of the dominant norms of international society coincided with a significant increase in China's power resources. During its first five year plan, finally begun in late 1952, growth rates were impressively high. US estimates put the annual increase in gross national product (GNP) at between seven and eight per cent in this period, with the expectation that, by the end of the decade, China would have 'tripled its electric power output, more than doubled its coal production, and increased the value of its machine industry some two and one whalf times'. This had been achieved on the basis of a political-economic model that represented a firm rejection of that offered by the liberalcapitalist states. These economic advances, coupled with China's holding the US armed forces-the most sophisticated military power in the global system-to a stalemate on the Korean battlefield, added to a picture in the 1950s of China as the 'wave of the future', ${ }^{10}$ able in the near term to develop an alternative and potentially attractive vision of international society that would appeal particularly to the newly-decolonised states and would be based on its own distinctive membership criteria. As Zhou Enlai put it at the first conference of Afro-Asian countries held in Bandung in 1955, the various delegations should put aside differences and band together on the 'common ground' of overturning the 'sufferings and calamities of colonialism'." 


\section{Power and Responsibility in Chinese Forelgn Policy}

Further Chinese challenges to the established diplomatic order were to come in the 1960s, although these were clearly less positive in terms of the political and economic outcomes for Beijing than had been the case in the 1950s. During Zhou's visit to Somalia in February 1964, he proclaimed-much to the chagrin of a number of the vulnerable, newly-decolonised states-'revolutionary prospects are excellent throughout the African continent'. 1965 saw the publication of Lin Biao's Long Live the Victory of People's War. It divided the world into the countryside (Asia, Africa and Latin America) and the cities (Europe and North America) and argued that a united front among the poor and oppressed in the Third World would overwhelm the oppressors in the metropole. The behaviour of its diplomats in overseas postings during the Cultural Revolution resulted in over a dozen countries severing diplomatic relations with China. Cambodia's Prince Sihanouk, for example, in September 1967, charged Beijing with interference in his country's internal affairs in violation of the five principles of peaceful coexistence. ${ }^{12}$ Beijing also decided to bring home all but one of its diplomatic personnel from abroad during this period in order that they could undergo intensive re-education in Maoist revolutionary precepts. The domestic chaos was permitted such free rein that the central authorities lost control of the Chinese foreign ministry for a time; and in Beijing the British mission was set on fire.

More broadly, China's contribution to global discourse on some of the core issues of the day connected with peace and security appeared particularly uncompromising. It depicted the arms control negotiations between the two superpowers as a sham and an attempt to impose hegemonic control, the Bretton Woods Institutions as leading predators in a capitalist economic order, and the United Nations in 1965 as a 'dirty international political stock exchange in the grip of a few big powers'. It charged that the Special Committee for Peacekeeping Operations was part of a plot to convert the United Nations into a 'US-controlled headquarters of international gendarmes to suppress and stamp out the revolutionary struggles of the world's people'. ${ }^{3}$ China's determination to force a breach in relations with the Soviet Union 
in the early 1960s made more prominent still its role as outsider even within its nominal identity group, especially at a time when Moscow and Washington had embarked on negotiations that illustrated their Great Power management role and common purpose in the avoidance of nuclear war. ${ }^{4}$ Beijing's promotion of a vision of a world in flux, one where hegemons had to be weakened and old political orders overthrown, rendered it a determined opponent of international society, not a potential new entrant into the club of responsible states.

\section{China as candidate Great Power and responsible state}

Undoubtedly, China was always more complex as an international actor than the depiction presented so far. An identity as a radical socialist revolutionary state was clearly important to its leaders, but there was always another identity - that of a Great Powerthat Beijing sought to acquire, together with the mutual acknowledgment if not respect of other powerful states in the system.The PRC, for example, wanted the seat on the UN Security Council that was held by the Guomindang (GMD); it delighted in its participation in Great Power deliberations at Geneva in 1954:15 and it moved to develop and promote such norms of international conduct as the five principles of peaceful coexistence with its own stress on the value of state sovereignty, mutual interest, and noninterference. Like the other major states, it also began to embark on an overseas aid program even though its populace was poorer than many of its aid recipients.

Although China promoted the perception that it gave unqualified support to revolutionary movements wherever they might arise, in fact its level of support in the 1960s depended on the degree to which they, or the state of which they were a part, were willing to adopt policies acceptable to Beijing. It was 'not the objective class character of the society in question or the proclaimed ideology of the party in power ${ }^{16}$ that determined the attitudes of Chinese leaders. Moreover, for some of the weaker states in the global system, particularly those that had emerged from anti- 


\section{Power and Responsibility in Chinese Foreign Policy}

colonial struggles, Chinese actions did not go beyond the bounds of appropriate behaviour. They were favourably disposed towards states such as China that had rendered them some assistance, even if that assistance had often only been verbal. Ambiguities in international law on the subject of the non-use of force in respect of national liberation movements ${ }^{17}$ also undermined some of the claims that China was failing to uphold the principles of the UN Charter.

Yet, in the 1950s and 1960s, Chinese behaviour overall was overwhelmingly interpreted as reflecting a desire to articulate new conceptions of international society based on China's own historical and political-economic experiences, not as attempts to enter the existing club of Great Powers. Its more traditional diplomatic actions at the state-to-state level were insufficient to sway the dominant image of China as, quite probably, the most radical of the revolutionary states in the global system.

That depiction of China was to change, however, with China eventually seen more as a 'system maintainer', even 'system exploiter' than a 'system challenger' from the 1970s and early 1980 s onwards. ${ }^{18}$ During this period Beijing started to establish diplomatic relationships on a global basis, entered the United Nations (1971), and the Bretton Woods Institutions (1980) and, crucial to all these developments, improved and then normalised its relationship with the United States, even at the expense of its erstwhile socialist allies in Asia-North Korea and Vietnam. In the 1970s, despite greater international engagement, it still did not take on the responsibilities that came with its position as one of the Permanent 5 on the UN Security Council. It remained passive in the United Nations, failing to participate in many of the organisation's statutory subsidiary bodies, rarely sponsoring a draft resolution, or using its veto. ${ }^{19}$ It continued to reject deep engagement in the global economy. Its decisions about trade reflected the principles of import substitution. It incurred neither foreign nor domestic debt, nor made use of foreign direct investment. Only gradually, especially after Mao's death and the introduction of Deng Xiaoping's reform agenda, during which 
"Chinese themselves repudiated the "Chinese model", ${ }^{20} \mathrm{did}$ the Beijing leadership begin to act as though it wanted to fulfil the entry requirements of contemporary international society.

Those entry requirements still related to the idea of Great Power management of the system, but in the 1980s a responsible state had also come to be perceived as one that was in good standing in the international regimes that made up the substance of international life. ${ }^{21}$ International regimes and organisations had rapidly advanced in number and issue area by this decade-to contribute to the central international society goal of international peace and security, expectations were that a state be involved with, among other matters, arms control arrangements, UN peacekeeping operations, the protection of the environment, and be supportive of the world trading order, all areas where China began to participate more fully.

This normative agenda, albeit demanding enough in its own terms, was to be further developed through the late 1980s and early 1990 s. Connected strongly with the ending of the Cold War, but also representing a longer process of normative change, there was a third turn in meaning associated with the responsible state in international society. This involved new and broader understandings of the concept of security to embrace intra-state relations, and the idea of human security and human rights. The responsible state thus came to include one that was concerned less with the division between the domestic and international realms, but one that demonstrated a willingness to promote individual security within states and to foster legitimate forms of representation through adherence to democratic forms of government. An earlier conception of international society had rested on an understanding of sovereignty that emphasised nonintervention and non-interference and the freedom to act independently. Over the course of the post-war and especially post-Cold War eras, however, these normative foundations were to be weakened by the advent of global actors other than states, the embedding and development of different norms, and the creation of additional regimes designed to manage a more 


\section{Power and Responsibility in Chinese Foreign Pollicy}

interdependent global system. Rather than building an international order of states that accepted differences in values but attempted to define a set of common interests, now there was a concern with world order, a desire to promote convergence towards certain core values, and a focus on the sovereignty of individuals rather than of states. The breakdown of the ideological Cold War divide provided new structural conditions that made it possible to promote ideas that affected directly the domestic organisation of states, and space to contemplate the methods necessary to bring about convergence towards a set of common values on which a solidarist global society could rest.

Much of the writing on state sovereignty in the 1990s, then, points to this third evolution in our understanding of what it means to be a sovereign state, ideas that are often subsumed under the term legitimate sovereignty. Legitimate sovereignty refers not just to an ability to control territory and peoples and to achieve recognition of that fact, or to be in good standing in international regimes, but now implies acceptance of certain rules that result in particular domestic structures. As Jack Donnelly has observed in reference to human rights, there has come into being a new standard of civilisation-states will only be entitled to full membership of international society to the extent that they meet the new criterion of observing international human rights standards. As he explains it, "human rights represent a progressive late twentieth century expression of the important idea that international legitimacy and full membership in international society must rest in part on standards of just, humane or civilised behaviour'. He goes on, noting that 'despite the continuing split between national and international law embodied in dominant conceptions of sovereignty, the society of states has come to accept that our common humanity makes the way in which any state treats its citizens a legitimate concern of other states, foreign nationals and international society'. ${ }^{22}$

This, however, is not just the view of scholars working in this issue area. Many governments and their officials during this period demonstrated that they were already attuned to these requirements, some of whom resented these expectations as impositions by the strong, and others of whom either agreed with 
these broader goals or perceived them as an opportunity to indicate that their state had embarked on a new path. In the late 1980 s, for example, the Soviet Foreign Minister, Eduard Shevardnadze, said to an audience of Soviet diplomats: 'The image of a state is its attitude towards its own citizens, respect for their rights and freedoms, and recognition of the sovereignty of the individual'. With the advent of political change within the former Soviet bloc, Hungary decided to signal aspects of its new identity when in 1988 it became the first East European state to ratify the Optional Protocol of the International Covenant of Civil and Political Rights - the right of petition for individuals who claim to be victims of a violation by a State Party. ${ }^{23}$ Many states made similar moves, for example, Brazil and Indonesia, both of which set up National Human Rights Commissions as part of this desire to signal a change in domestic political behaviour.

Some of the major international institutions also came to be associated with the promotion of democratic politics and the humane treatment of one's citizens, often under the heading 'good governance'. While the World Bank has been constrained by its Articles of Agreement from advocating pluralist democracy, its definition of governance comprises such matters as improving accountability, transparency, the promotion of civil society and the rule of law. ${ }^{24}$ Progress towards these goals and policies on military spending are taken into consideration when the World Bank makes lending decisions. The European Bank for Reconstruction and Development incorporated into its founding charter the requirement that aid recipients be "committed to applying the principles of multi-party democracy, pluralism and market economies'. The Organization of American States (OAS) adopted a resolution in June 1991 that, in its preamble, required the 'political representation of [member] states to be based on effective exercise of representative democracy'. The resolution called for the organisation's Secretary-General to hold an immediate meeting of the OAS Permanent Council in the event of any occurrences giving rise to the sudden or irregular interruption of the democratic political institutional process or of the legitimate exercise of power by the democratically elected government in any of the Organization's member states'. ${ }^{25}$ Although 


\section{Power and Responsibility in Chinese Foreign Policy}

the supremacy of the norm of democratic entitlement may be honoured more in the breach than in the actual fulfilment, nevertheless by the mid 1990 s some 130 governments had announced a legal commitment to holding open, multiparty elections based on a secret ballot and universal franchise. Moreover, many political actors had sought international validation of these electoral processes-that is, had decided to invite 'interference' in their own domestic affairs. International observers have been used not only to show to the world the country's commitment to democracy, but also to confirm the fairness of the result to domestic audiences, thereby undermining the basis for any internal challenge to the authority of the newly elected. ${ }^{26}$

Alongside the development of state-based international organisations, there has been a vast increase in the numbers and influence of non-governmental organisations (NGOs) in recent years. These too have created new norms and have played roles in shaping the determination of whether a government deserves the title responsible or not. NGOs, as new sites of authority, ${ }^{27}$ can influence international perceptions of a particular state through the information they provide and their transnational networking capabilities. Their capacities can be considerable--between 1950 and 1993, the number of groups working primarily on human rights was estimated to have increased fivefold, doubling between 1983 and $1993 .{ }^{28}$ One of the most prominent, Amnesty International, has built up a staff size and budget that compares favourably with the level of resources that the United Nations devotes to human rights issues as a whole. ${ }^{29}$ NGOs have provided a vital input into such UN bodies as the UN Commission on Human Rights, the Human Rights Committee, the Committee against Torture, as well as working with individual governments and the world's media. These UN bodies are highly dependent on the information provided by the human rights NGOs, especially when attempts are made to move beyond the setting of standards into the monitoring of compliance. The pressure to conform to some notion of a common good now comes, therefore, from many different points of the system, rendering it difficult for any state to avoid some of the negative consequences of transgressing the dominant norms of the current global order. 


\section{China's fulfilment of the new criteria}

Neither political actors nor scholars are in agreement as to whether China seeks to fulfil over time all, some, or only a limited number of the current requirements for membership in the club of the responsible. Such an assessment is complicated because we have no clear signposts as to how much participation is enough to acquire the designation 'responsible', and because we have moved from what one scholar has labelled an international gemeinschaft community - a tighter more coherent community-to a gesellschaft - a looser more informal society. ${ }^{30} \mathrm{~A}$ looser international society implies a larger range of views over what constitutes the dominant norms and a weakening of the basis of agreement over what best promotes international, or perhaps it would be more accurately described as global, order.

The developmentalist and cultural relativist rhetoric in the human rights area, for example, challenges the idea of the indivisibility and universality of human rights. Developmentalist arguments suggest that both domestic and international order is best maintained by states that are economically strong and advanced, and that the protection of civil and political rights has to give way when necessary to that larger goal of economic development. Moreover, this particular argument over human rights is difficult to interpret. It leaves observers unsure as to whether states such as China would otherwise seek to reach international standards as quickly as possible but for the constraint of their relatively low levels of economic development.

The assessment of compliance with the criteria for responsible statehood is made more problematic still because some major international regimes allow considerable room for manoeuvre, including the expectation of a period of delay when it comes to domestic implementation, a willingness often to accept procedural compliance without real fulfilment of regime norms, and a lack of action when states weaken treaties by filing reservations at the time of ratification.

The interpretation of behaviour in this looser international society is made even more difficult by the realisation that consensus, on which states exhibit responsible behaviour is, and has always 
been, a highly political act. The views of the most powerful states have always dominated, especially those of the United States since 1945. The hegemonic position of the United States, which derives from its all-round strength as a state and its influential role in many of the multilateral international organisations, has led it to take on what it and certain others perceive as a custodial role in the global system. Yet that same perceived role-what W. Michael Reisman describes as the 'actor of last resort in matters of fundamental importance to contemporary international politics'has brought the United States to act unilaterally, and at times unlawfully, to preserve the ultimate goals of international society as it perceives them. ${ }^{31}$ China and other states have justifiably cried hypocrisy and pointed to double standards when these instances of unlawful behaviour occur, but despite these criticisms, states have continued to invoke America's custodial role in moments of crisis. Nor have these criticisms made the United States refrain from labelling states 'rogue' or 'responsible', or as being in international society or outside of it.

On the eve of Premier Zhu Rongji's April 1999 visit to Washington, President Clinton on the whole described China's global and regional roles in positive terms, in marked opposition to the kinds of sentiments expressed in the US Congress and parts of the US media. China, he said, had helped convince North Korea to freeze the production of plutonium and refrain from further missile tests; it had helped avert nuclear confrontation in South Asia in 1998; in the 1990s it had joined the Non-Proliferation Treaty, the ChemicalWeapons Convention, the Biological Weapons Convention and the Comprehensive Test Ban Treaty (CTBT), and accepted the safeguards, reporting requirements and inspection systems that went with them. It no longer provided assistance to Iran's nuclear program, had stopped selling Iran anti-ship cruise missiles, and had halted assistance to Pakistan's nuclear facilities. In the environmental arena, China and the United States were working together on developing cleaner technologies and cutting pollution. He hoped for and expected further progress on China's bid for membership in the World Trade Organization (WTO), with China finally agreeing to open its internal markets. ${ }^{32}$ It was a 
remarkably positive picture that projected China as being in good standing in many of the core regimes of the global system, a country that over the course of the 1980s and 1990s had stepped inside the tent in many key areas of concern.

Academic analyses of security questions, economic integration, and the environment have also reached some reasonably positive conclusions about Chinese behaviour. In disarmament and arms control negotiations, Michael Swaine and lain Johnston argue that the Chinese perspective has shifted over the last $10-15$ years from viewing arms control as largely irrelevant to its concerns to a position that recognises that there are benefits to be had from participation. Whereas it had signed up to only 10-20 per cent of the arms control arrangements for which it was eligible in 1970 , by 1996 this had reached 85-90 per cent. Much of this more positive behaviour, according to Swaine and Johnston, relates to China's wish to be viewed as responsible - in reference to Beijing's signature of the CTBT, they note that Chinese officials felt a pressure to join the process and move towards signature in tandem with other members of the UN Security Council and once clear support for the treaty emerged among the developing countries. China signed the CTBT even though this represented a considerable 'sacrifice' for China and a constraint on its power. ${ }^{33}$ With respect to China's increased participation in UN peacekeeping operations, observers have noted that developing countries have pushed Beijing to become more actively involved in an activity that they saw as beneficial to domestic stability and regional peace, ${ }^{34}$ similarly suggesting a Chinese concern with its international image.

Concerning the international trade regime, Margaret Pearson notes that China has made substantive concessions to gain entry to the WTO, has restructured its laws and regulations to attract foreign technology, investment and trade and has joined the global intellectual property rights regime. Further progress along these lines will be troublesome, but overall, Pearson concludes, it is 'difficult not to be impressed with the speed, magnitude, and depth of China's integration into the global economy during the postMao era'. ${ }^{35}$ Many have commented on the social and economic costs that Chinese workers will initially bear as a result of 
membership of the WTO-especially those in much of the stateowned sector-but China has expressed its desire to take its place in this organisation both in order to reap economic advantages over the longer term, and out of a concern to establish its rightful place in the world's most important trading body. China's environmental policies have exhibited a similar blend of incremental progress, Lester Ross has argued. Beijing has become extensively involved in environmental treaties, provided these are not perceived to constrain its search for higher levels of economic development. Some of the domestic consequences of this involvement include the development of new institutions to help with the implementation of treaty requirements, ${ }^{36}$ suggesting a sustained commitment to these decisions. It could be expected that China's new environmental bureaucracies would resist any attempts by Beijing to reverse course.

Obviously the nature of the international regime in question, especially its level of intrusiveness, the extent to which it might erode strategic independence, threaten political control or actually serve to enhance China's power have influenced Beijing's compliance and involvement, for reasons that have become familiar in studies of Chinese foreign policy behaviour. Clearly, China benefits materially from membership in multilateral organisations such as the World Bank, where it has long been the largest recipient of the Bank's development aid. Thus, instrumental interest may explain its cooperative and compliant behaviour in this instance, alongside the conditions for membership that each of the economic organisations imposes.

In other issue areas such instrumental reasoning is more difficult to advance. What becomes more salient is a Chinese concern for its international image and a desire to be regarded as a cooperative and responsible great power. Beijing constantly refers to its good record in adhering to the core regimes of international society, often contrasting its supposedly favourable record with that of the 'unilateralist', 'hegemonic' United States. In the area of arms control, China has acceded to treaties that have imposed some constraints on its military power since 1980, even though nonparticipation was unlikely to have incurred severe material costs. ${ }^{37}$ 


\section{China and the idea of a responsible state}

Although Beijing is extremely wary of Security Council authorisations under chapter VII provisions of the Charter (these relate to enforcement measures in reference to breaches of the peace) between 1990 and 1999 Beijing supported these 84 per cent of the time, abstaining on the rest. ${ }^{38}$ Even in the problematic area of human rights, China has signed the two international covenants, and accepted some domestic scrutiny of its practices by the UN High Commissioner for Human Rights, a UNWorking Group and one of the United Nation's special rapporteurs. This participation in the international human rights regime came partly in an attempt to undercut support for a draft resolution at the UN Commission on Human Rights that would condemn its human rights record. States have long since given up their attempts to impose economic and political sanctions (military sales remain the exception) against China as a result of its lapses in the human rights area, and the human rights regime itself does not contain material enforcement mechanisms. Nevertheless, even in the absence of such directly coercive means, China has been steadily drawn into procedural if not substantive support of a regime that in some senses represents a threat to Communist Party rule. ${ }^{39}$ With the exception of some in the US Congress, certain members of the current Bush administration, and more widely the proponents of the 'China threat' school, many would accept on the basis of this record that in a number of areas China has become more responsible since the 1980s, especially in comparison with its behaviour in the first two decades of the PRC's existence.

Why China should be concerned about international image and an identity as a responsible state is not easy to explain, and the concern may arise for different reasons in diverse policy areas. Some leaders may also be more concerned about image-the foreign ministry, for example-than others. The explanation for its normative compliance in areas where instrumental reasons seem relatively weak appears to relate to a desire, particularly in multilateral venues, not to be singled out for disapprobation. Verbal sanctioning-potential or actual-argumentation and persuasion have had the effect of enhancing China's adherence to certain norms that are shared by many others-Beijing has seen the need 
to link itself to what is seen internationally as appropriate standards of behaviour, to "mirror' the practices of significant others over time'. ${ }^{40}$ As Johnston and Evans report with respect to the arms control arena, 'in interview after interview of arms control specialists, [and in documents for internal circulation] a common response was that China had to join such and such a treaty or process because it was part of a world historical trend, because it was part of China's role as a responsible major power, because it would help improve China's image, and, more concretely, help China to break out of the post-June 4 attempts by some Western states to isolate China diplomatically'. ${ }^{41}$

\section{The new standard of civilisation: human rights and democratic governance}

A number of governments and scholars are still reluctant to depict China as a responsible state because it is not yet clear how China will utilise the material power accumulated during economic reform over the longer term. To some extent, this relates to Beijing's stated willingness to use force, if necessary, to solve the Taiwan reunification issue and the suspicion that it might be willing to do the same in reference to outstanding claims in the South China Sea. China's domestic political arrangements have added to the uncertainty. President Clinton's positive appraisal of China, outlined above, inevitably contained less positive aspects, including calls for Beijing to 'respect the human rights of its people and to give them a chance to shape the political destiny of their country'. Many of the other democratic states would agree with this call and are motivated to pursue 'bilateral dialogues' with China in part to enhance the prospects for Beijing's adherence to international human rights standards. The Chinese government has been made aware that these matters of human rights and democratic governance have become the new standards of civilisation, the new set of criteria for membership in international society. This understanding helps explain why China decided in 1997 and 1998 to sign the two key covenants of the international human rights regime-first, the International Covenant on Economic, 
Social and Cultural Rights on the eve of President Jiang Zemin's 1997 summit in Washington, and then, in October 1998, the International Covenant on Civil and Political Rights as the United Nations began celebrations for the fiftieth anniversary of the Universal Declaration of Human Rights (UDHR). ${ }^{42}$ As of June 1997, it was joining 138 state parties to the Covenant on Civil and Political Rights, and I 36 to the Covenant on Economic, Social and Cultural Rights, an act that signalled Chinese understanding of the new normative requirements and an unwillingness to remain an outsider in the UDHR's celebratory year.

Nevertheless, the human rights and democratic governance criteria for membership in international society are extraordinarily difficult for Beijing to satisfy because they threaten core values of the Party-State.The Chinese leadership witnessed the way in which political activists in the former Soviet Union and in Eastern Europe used those governments' signatures to the human rights provisions of the 1975 Helsinki Accords to publicise their demands and to exercise political leverage. Although Beijing has expounded the benefits of developing a rule of law ${ }^{43}$ and has introduced much new legislation designed to improve human rights protections, proper adherence to international standards threatens Party rule and the leadership's view of how to secure domestic political and social stability. When Party leaders see what they regard as dangerous evidence of instability, they promote the so-called 'strike-hard' campaigns, which send signals to those in charge of law enforcement to cut corners to increase the numbers of arrests and convictions. Organised political activity not sanctioned by the Communist Party invites swift retribution and only cursory reference to the new criminal codes. Calls for the development of multi-party democracy elicited a statement by Li Peng-Chair of the National People's Congress-to a German newspaper that any independent group that tried to 'go for [a] multiparty system [or] to negate the leadership of the Communist Party [would] not be allowed to exist... China promotes democracy and practices the rule of law but our road is not patterned on the Western approach that features the separation of powers, a multiparty system and privatization'. ${ }^{44}$ 
Similarly alarming from Beijing's perspective has been the international debate over humanitarian intervention in response to evidence of gross violations of human rights, as articulated in a conspicuous form by the UN Secretary-General in September 1999. Kofi Annan's speech to the $54^{\text {th }}$ session of the UN General Assembly averred that the global community had learned that it could not stand idly by watching gross and systematic violations of human rights, that state sovereignty was being redefined to encompass the idea of individual sovereignty, and that in our contemporary reading of the UN Charter we were 'more than ever conscious that its aim is to protect individual human beings, not to protect those who abuse them'. ${ }^{45}$ The Chinese government, although it was by no means alone, took a particularly strong stand against these ideas, preferring instead to highlight the benefits of a more traditional definition of state sovereignty and noninterference. Beijing argued that these were the 'basic principles governing international relations', and that their absence would lead to new forms of 'gunboat diplomacy' that would 'wreak havoc'. More revealing still were alarmist Chinese statements in response to NATO's military intervention in Kosovo following the bypassing of China's and Russia's expected veto of any resolution tabled at the UN Security Council. In an authoritative article in Renmin Ribao, 'US-led NATO' was described as having 'cooked up' the 'absurd theory that 'human rights transcend sovereignty". NATO's action demonstrated that

once the United States believes that an incident of some kind has happened in one of these [developing and socialist] countries that does not fit US-style human rights or suit US interests, the United States can interfere in that country's internal affairs, violate its sovereignty, and even resort to the use of force, under the pretext that 'human rights transcend sovereignty'. ${ }^{46}$

As with the original European-based concept of international society, the Chinese government interprets the advancement of norms relating to humanitarian intervention, human rights and democratic governance as an imposition of the strong on the weak, based on a presumption of the superiority of values in one 
civilisation over those of another. For a time, other countries that had espoused cultural relativism or a commitment to Asian values had provided some protection and support for China and a period of respite, but this particular discourse faded in the wake of the Asian economic crisis. Nevertheless, many developing countries, along with China, do continue to see the concept of non-interference and sovereign equality as the final defence against the rules of a divided, unequal world. Beijing's interpretation of sovereignty highlights its identity as former semi-colony and Third World socialist state, not its position as Great Power with UN Security Council membership, nuclear weapons, and rising economic clout in the global economy. As such, its views can form the basis for a coalition among some of the weaker states in the global system, states that endorse China's arguments that the strong are not held to the same standards of accountability. Beijing is struggling to muster these forces in support of the more traditional definitions of state sovereignty against a normative order that has already shown clear signs of moving beyond this earlier and stricter interpretation. China is caught between the need, on the one side, to build coalitions with states that reinforce an identity that it has been trying to shed and, on the other, a desire to embrace the norms articulated by the most powerful states and influential international organisations in the global system.

Chinese leaders argue in response to criticism of China's domestic arrangements that they deserve praise and not blame for the developments that have occurred since 1949-that they have achieved enough domestically over the past five decades to satisfy the rules of international society. The Party has united the country, ended decades of civil war, sustained civilian rule, pacified the country's borders and most recently brought millions out of poverty. Despite these achievements, however, all of which have come at great cost to individuals, families, and communities, Beijing cannot escape the fact that the normative agenda of international society has expanded, as have the ambitions of China's domestic political reformers. Many of these reformers and political activists perceive in international human rights standards and in ideas of legitimate sovereignty the key to real political development in 


\section{Power and Responsibility In Chinese Forelgn Policy}

their country. ${ }^{47}$ Undoubtedly, many outside and inside the country recognise that shifts from authoritarian rule to a more democratic form of governance are hazardous and pose enormous challenges to the maintenance of domestic order and thus to the stability of China's neighbours. Nevertheless, a continuing failure to address political reform in a serious way, on balance, risks more than trying to cling to the current political arrangements. If such change were seriously to be attempted, incrementally through constitutional and institutional reform, then this would clearly warrant China's depiction as a state responsible not only in the international but also in the domestic realm. In the absence of such shifts, China will, in important ways, remain outside global society.

\section{Acknowledgment}

An earlier version of this paper was published in The China Journal, 45 , January $2001: 1-19$. The author is grateful for all the comments received on earlier versions of the paper and also thanks The China Journal for permission to reprint the article in slightly updated form in this edited collection.

\section{Notes}

1 Reading that is relevant to these polar positions includes Ross Munro and Richard Bernstein, 'China l: the coming conflict with America', Foreign Affairs, 76, no. 2 (March 1997):18-32; Robert S. Ross, 'Beijing as a conservative power', Foreign Affairs, 76, no. 2 (March 1997):33-44; David Shambaugh, 'Containment or engagement of China? Calculating Beijing's response' International Security, 2I, no. 2 (Fall 1996): 180-209; James Shinn (ed.), Weaving the Net: conditional engagement with China (New York: Council on Foreign Relations Press, 1996); Stuart Harris and Gary Klintworth (eds), China as a Great Power: myths, realities and challenges in the Asia-Pacific region (New York: St. Martin's Press, 1995). For one important reaction from the East Asian region see Jose T. Almonte, 'Ensuring security the ASEAN way', who has written: 'East Asia's greatest single problem is how to incorporate China into its regional arrangements-how to 'socialise' the country by reducing the 


\section{China and the ldea of a responslble state}

element of threat while accentuating the positive elements in China's regional relationships'. Survival, 39, no. 4 (Winter 1997-98):8092.

2 Hedley Bull, The Anarchical Society: a study of order in world politics (London: Macmillan, 1977).

3 For a valuable discussion of Hedley Bull's work and his explanation of pluralist (accepting an ethic of difference) and solidarist (the idea of a global common good) conceptions of international society see Kai Alderson and Andrew Hurrell (eds), Hedley Bull on International Society (Basingstoke: Macmillan, 2000), especially chapter 1.

4 To name but three of these criteria, the concepts of good governance, humanitarian intervention and protection of human rights pose particular challenges.

5 See Gerrit W. Gong, The Standard of 'Civilisation' in International Society (Oxford: Clarendon Press, 1984); G.W. Gong, 'China's entry into international society' in Hedley Bull and Adam Watson (eds), The Expansion of International Society (Oxford: Clarendon Press, 1984):171-84; Yongjin Zhang, China in the International System, 191820: the Middle Kingdom at the periphery (Basingstoke: Macmillan, 1991).

6 Chen Jian, China's Road to the Korean War: the making of the SinoAmerican confrontation (New York: Columbia University Press, 1994): chapter 2 and p. 59.

7 Chen Jian, China's Road, especially p. 10 and pp. 73-75; Cold War International History Project, 'The Cold War in Asia', Cold War International History Project Bulletin, Issues 6-7, Winter 1995/96 (Washington DC:Wilson Center); Qiang Zhai, China and the Vietnam Wars 1950-1975 (Chapel Hill: University of North Carolina Press, 2000); and more generally J. David Armstrong, Revolution and World Order: the revolutionary state in international society (Oxford: Clarendon Press, 1993).

8 Steve Chan, 'Chinese perspectives on world order', in T.V. Paul and John A. Hall (eds), International Order and the Future of World Politics (Cambridge: Cambridge University Press, 1999), 203.

9 Department of State 'National Intelligence Estimate (NIE): 'Chinese Communist capabilities and probable courses of action through 1960', Foreign Relations of the United States, 1995-57 (Washington DC: Government Printing Office, 1986), 3:230-55; 'NIE: Communist China through 1961', Foreign Relations 1955-57, 3:497-510. 
10 As a US National Security Council staff study of 6 November 1953 put it: "The achievement of the Chinese Communist regime in Korea has been a military defeat of no mean proportions, and instructive as to the extent of Chinese Communist military capabilities. The Chinese Communists, with Russian assistance, were able to organise, train, equip, supply, and commit massive ground forces in the Korean peninsula. These forces fought with courage, aggressiveness, and with notably few desertions'. Department of State, Foreign Relations 1952-54, 14:289-90. The 'wave of the future' reference is taken from a private statement by the US Secretary of State, John Foster Dulles, to the press on 18 February 1957. See Department of State, Foreign Relations 1955-57, 3:482.

1 Quoted in Department of State, Foreign Relations 1955-57, 3:251.

12 See Peter Van Ness, Revolution and Chinese Foreign Policy: Peking's support for wars of national liberation, (Berkeley, California: University of California Press, 1970), 201.

13 Samuel S. Kim, 'Thinking globally in post-Mao China', Journal of Peace Research, 27, no. 2 (1990):193; Beijing Review, 10, no. 5 (March 1965.

14 China's direct and open criticism of the Soviet Union began after Moscow signed the Partial Test Ban Treaty in 1963.

15 As a Renmin Ribao editorial put it after China's participation at the Geneva Conference on Korea and Indo-China: 'For the first time as one of the Big Powers, the People's Republic of China joined the other major powers in negotiations on vital international problems and made a contribution of its own that won the acclaim of wide sections of world opinion. The international status of the People's Republic of China as one of the big powers has gained universal recognition'. Quoted in Michael B. Yahuda, Towards the End of Isolationism: China's foreign policy after Mao (London: Macmillan, 1983), 100.

16 Van Ness, Revolution and Chinese Foreign Policy, 189.

17 This ambiguity is discussed in Adam Roberts and Benedict Kingsbury (eds), United Nations, Divided World: the UN's roles in international relations (Oxford: Clarendon Press, 1993), 22-29.

18 These terms were first introduced by Samuel S. Kim. For one example of their use see his 'China's international organizational behaviour', in Thomas W. Robinson and David Shambaugh (eds), Chinese Foreign Policy: theory and practice (Oxford: Clarendon Press, 1994), 431.

19 Discussion of this passivity is in Samuel S. Kim, China, the United Nations and World Order (Princeton: Princeton University Press, 1979). 


\section{China and the idea of a responsible state} International and three cases of change in international human rights standards', (PhD dissertation, University of Minnesota, 1995), 8. Rick Fawn and Jeremy Larkins (eds), International Society after the Cold Wor (Basingstoke: Macmillan, 1996), 262.

3) W. Michael Reisman, "The United States and international institutions', Survival, 41, no. 4 (Winter 1999-2000), 63. Reisman

Gordon White, Riding the Tiger: the politics of economic reform in postMao China (London: Macmillan, 1993), 3.

Using Stephen Krasner's formulation, regimes are usually defined as the 'sets of implicit or explicit principles, norms, rules and decision-making procedures around which actors' expectations converge in a given area of international relations'. S.D. Krasner, (ed.), International Regimes (Ithaca, NY: Cornell University Press, 1983). For more on this idea of good standing See Abram Chayes and Antonia Chayes, The New Savereignty: compliance with international regulatory agreements (Cambridge, Massachusetts: Harvard University Press, 1995), 27; and Thomas M. Franck, The Power of Legitimacy Among Nations (New York: Oxford University Press, 1990), 190.

Jack Donnelly, 'Human Rights: a new standard of civilization?', International Affairs, 74, no. I (January 1998): 18, 21.

Shevardnadze quoted in Opening Speech by Lord Howe to Amnesty International London Seminar on Human Rights in China, 9 September 1996, 2. Information on Hungary from Dominic McGoldrick, The Human Rights Committee: its role in the development of the International Covenant on Civil and Politics Rights (Oxford: Clarendon Paperbacks, 1994), 17-18.

World Bank, Governance: the World Bank's experience (Washington DC: 1994).

Quoted in Thomas M. Franck, Fairness in International Law and Institutions (Oxford: Clarendon Press, 1995), 113.

Franck, Fairness, 117-18.

See Ann Marie Clark, 'Non-governmental organizations and their influence on international society', Journal of International Affairs, 48, no. 2 (Winter 1995):507-26.

Margaret E. Keck and Kathryn Sikkink, Activists Beyond Borders: advocacy networks in international politics, (Ithaca, NY: Cornell University Press, 1998), 10-11.

A.M. Clark, 'Strong principles, strengthening practices: Amnesty

Barry Buzan, 'International society and international security', in 


\section{Power and Responsibility In Chinese Foreign Pollcy}

also points to other factors that complicate the US role in multilateral institutions and contribute to its inconsistent behaviour: its 'prophetic and reformist role', its 'infra-organisational role', and its 'domestic-pressure reactive role'.

President Clinton's speech on US foreign policy, given at the Mayflower Hotel, Washington, under the auspices of the US institute of Peace, 7 April 1999 (published as NAPSNET Special Report, 8 April 1999). Of course, President Clinton was making these remarks partly in the hope of generating a positive atmosphere within the United States and between himself and Prime Minister Zhu on the eve of the visit.

Michael D. Swaine and Alastair lain Johnston, 'China and arms control institutions', in Elizabeth Economy and Michel Oksenberg (eds), China Joins the World: progress and prospects (New York: Council on Foreign Relations Press, 1999), 100-101, 108; Johnston and Paul Evans, 'China's engagement with multilateral security institutions', in Alastair lain Johnston and Robert S. Ross (eds) Engaging China: the management of an emerging power (London: Routledge, 1999), 251.

$34 \mathrm{Kim}$, 'China's international organizational behaviour', 421.

35 Margaret M. Pearson, 'China's integration into the international trade and investment regime', in Economy and Oksenberg, (eds) China Joins the World, 191.

36 Lester Ross, 'China and environmental protection', in Economy and Oksenberg (eds), China Joins the World.

37 Johnston and Evans, 'China's engagement', 247-5I.

38 it voted for 91.5 per cent of all the 625 resolutions passed in this period. For details see Sally Morphet, 'China as a Permanent Member of the Security Council, October 1971-December 1999', Security Dialogue, 31 , no. 2 (2000), Table 2, 154, 160. This compares with a 42 per cent level between November 1971 and December 1981; 66.7 per cent 1982-86; and 86 per cent 1986 and July 1990. With reference to chapter VII resolutions, it is worth noting that the period 1990-99 included the Gulf War, the wars in the former Yugoslavia, Somalia, Liberia, Rwanda, East Timor, and so on (some 174 chapter VII resolutions in all).

39 For a fuller exposition of this argument see Rosemary Foot, Rights Beyond Borders: the global community and the struggle over human rights in China (Oxford: Oxford University Press, 2000).

40 The influence of norms in socialising states and in inducing compliance with international regimes is discussed in such works 
as Chayes and Chayes, The New Sovereignty; Martha Finnemore, 'Constructing norms of humanitarian intervention', in Peter Katzenstein (ed.), The Culture of National Security: norms and identity in world politics (New York: Columbia University Press, 1996); Franck, The Power of Legitimacy; Audie Klotz, Norms in International Relations: the struggle against Apartheid (Ithaca, NY: Cornell University Press, 1995); and Harold Hongju Koh, 'Why do nations obey international law?', Yale Law Journal, 106, no.8 (1997). The idea of 'mirroring' others' behaviour as a result of social interaction is discussed in Alexander Wendt, 'Anarchy is what states make of it: the social construction of power politics', International Organization, 48, no. 2 (Spring 1992), 397.

41 Johnston and Evans, 'China and multilateral security institutions', 253.

42 China has now ratified the Covenant on Economic, Social and Cultural Rights but, as of writing (August 2001), not the Covenant on Civil and Political Rights.

43 In March 1999, the Chinese Constitution had been revised to read: 'The People's Republic of China shall be governed according to law and shall be built into a socialist country based on the rule of law' See BBC Monitoring Reports, Summary of World Broadcasts, (SWB), Asia-Pacific, FE/3486 G/9-10, 18 March 1999.

44 'Li Peng on press freedom, legislation and political parties', Beijing Review, 4-10 January 1999, 35-42.

45 United Nations, 'General Debate', UN document A/54/PV.8, General Assembly (Washington DC: United Nations, 22 September 1999).

46 Chinese reactions can be found in Renmin Ribao, 14 May 1999, excerpted in Summary of World Broadcasts, FE/3535, G7-8, 15 May 1999; FE/3512, G/6, 19 April 1999; FE/3525, G/I, 4 May 1999; and International Herald Tribune, 24 September 1999.

47 As the tenth anniversary of the Tiananmen bloodshed drew near, Bao Tong, former aide to the deposed Zhao Ziyang claimed his constitutional right to free speech and the positive benefits that had come from earlier challenges to political orthodoxy: "Who says divergent views are of no avail? Every bit of progress China has made since the $5^{\text {th }}$ April Tiananmen Movement in 1976 and the third plenary session of the $11^{\text {th }}$ Party Central Committee in 1978... are all attributed to the Chinese common people's efforts to rectify and overcome the mistakes made by Mao Zedong'. Summary of World Broadcasts, B FE/3525, G/6-7, 4 May 1999. 